\title{
MEMBANGUN IMAJINASI DAN FANTASI MELALUI BUKU- BUKU CERITA BERGAMBAR UNTUK ANAK-ANAK
}

\section{Widyastuti Purbani}

FBS Universitas Negeri Yogyakarta

\section{Abstract}

In what so-called the era of image and imagination, the words magination and fantasy commonly receive negative connotation, and are usually misunderstood as destructive rather than productive, even among intellectuals and educators. This paper aims at giving clarification on the importance and contribution of imagination and fantasy in education and transformation of knowledge. Illustrations on how to stimulate young people's imagination and fantasy using picture books, and what kind of picture books have the ability to stimulate imagination and fantasy will be revealed at the later part of this writing.

\section{A. Pendahuluan}

Sampai akhir abad yang telah disebut sebagai 'abad kebangkitan imajinasi' (Tedjoworo, 2001) sekarang ini, imajinasi, apalagi fantasi, masih sering dianggap sebagai barang 'haram' di Indonesia. Bahkan, di antara para pendidik, masih sering kita dengar pernyataan-pernyataan yang mengandung pemahaman negatif terhadap imajinasi. Di antara kaum yang mestinya disebut intelektual, tidak jarang kita menemukan anggapan bahwa novel, apalagi cerita genre fiksi ilmiah atau science fiction tidak atau kurang bermanfaat bagi anak-anak atau remaja, karena sarat dengan imajinasi dan fantasi. Film-film kartun kurang mendapat apresiasi karena dinilai terlampau jauh melenceng dari realitas. Tak jarang kita menyaksikan anak-anak atau remaja yang dimarahi atau dibentak orang tua atau gurunya karena melamun atau berkhayal. Banyak ruangan baik di sekolah maupun di rumah terbiarkan kosong tanpa gambar, lukisan atau artefak lain yang mampu merangsang imajinasi. Guru dan dosen merasa harus hanya mengajarkan realitas. Akibatnya, pembelajaran menjadi sangat kering dari imajinasi, apalagi fantasi. Belajar menjadi kering akan pengembaraan.

Padahal imajinasi telah berabad menjadi 'orang tua' bagi bahasa, sekaligus 'orang tua' bagi realitas. Tidak seperti yang sering kita sangkakan, temyata imajinasi bukanlah turunan atau anak dari realitas. Sebaliknya, realitaslah yang merupakan turunan dari imajinasi. Dalam banyak kasus, imajinasi justeru mendahului realitas, sehingga secara ekstrim realitas dianggap tak lebih dari sekadar 'pantulan pucat dari imajinasi' (Tedjoworo, 2001: 17).

Harus diakui bahwa meluruhnya rasialisme dan diskriminasi terhadap warga berkulit hitam di Amerika banyak dipengaruhi oleh karya-karya imajinatif sastrawan dan pencipta film, yang gigih memerangi diskriminasi lewat teks-teks ciptaan mereka. Teks teks yang berupa koleksi mimpi dan cita-cita yang 
material pasal-pasal dan ayat-ayat yang ada di dalamnya. Demikian juga Agreement on Trade-Related Aspects of Intelektual Property Rights dan Undang-Undang Hak Cipta 1997 juga memiliki formulasi dan cakupan material hukum yang relatif jelas dan tegas. Kompleksitas karakteristik dan ragam karya seni berserta aspek ekonomis dan yuridis sudah dicoba dijadikan material hukum. Oleh karena itu, sejauh mencakup konstruksi umum perundangan hak cipta, hak cipta karya seni sudah cukup terlindungi. Di sini tampak tidak ada permasalahan krusial.

Secara khusus dan mikro memang terdapat kekuranglengkapan, kekurangjelasan, kekaburan, dan kekurangpastian dalam peraturan perundangan hak cipta di atas sebab semua peraturan perundangan [termasuk perundangan hak cipta dan terkait dengan hak cipta] selalu memiliki keterbatasan dan "bocor". Dalam pelbagai peraturan perundangan yang dikemukakan di atas, paham, bentuk, dan variasi karya seni beserta segala transformasinya yang beroleh perlindungan hak cipta kurang diformulasikan secara lengkap. Misalnya, tidak ada pasal dan aya yang mengatur transformasi tembang macapat Jawa dan Bali menjadi macapat Sasak, transformasi cerita Mahabharata dan Ramayana di dalam berbagai daerah di Indonesia, transformasi cerita Ramayana menjadi novel Anak Bajang Menggiring Angin karya Sindhunata, transformasi puisi lisan jadi puisi tulis, transformasi puisi tulis menjadi puisi audio dan audiovisual, epigonisme dan intertekstualitas yang lazim dalam karya satra, dan transformasi novel menjadi sinetron atau filem. Demikian juga tidak ada pasal dan ayat yang mengatur kemiripan-kemiripan karyakarya seni tradisi atau yang bercorak tradisi, misalnya kemiripan pertunjukan wayang yang menggunakan cerita sama dan kemiripan tembang macapat Sunda, Jawa, Bali, dan Sasak. Fungsi-fungsi karya seni di dalam masyarakat beserta implikasi nilai ekonomis dan sosialnya juga kurang dirumuskan secara jelas dan jernih dalam pasal atau ayat yang ada, misalnya apakah lagu-lagu spiritual atau rohani yang jelas siapa penciptanya yang digunakan oleh pihak tertentu untuk acara keagamaan dikenai izin dan kewajiban membayar royalti atau tidak. Peruntukan ekonomis karya seni tradisi yang hak ciptanya dipegang oleh negara juga perlu memperoleh formulasi yang jelas. Kewajiban dan tanggung jawab negara atau pemerintah selaku pemegang hak cipta seni tradisi dan karya seni lain yang sudah melewati batas perlindungan hak ciptanya sudah harus dijelaskan secara tegas dan tersurat, misalnya apakah karya seni yang menjadi benda bersejarah atau benda purbakala [patung, menhir, lukisan gua, dan sebagainya] harus dipelihara dan dirawat oleh pemerintah atau boleh dipelihara dan dirawat oleh individu. Materi, pasal, dan ayat pendaftaran hak cipta terkesan terlalu menuntut pemilik dan pemegang hak cipta untuk proaktif, sedangkan aparat hukum dan pemerintah terkesan dirumuskan pasif, tinggal menerima pendaftaran [seharusnya aparat penegak hukum juga harus proaktif]. Materi, pasal, dan ayat gugatan atas pelanggaran hak cipta terkesan sebagai delik aduan yang lebih banyak merepotkan seniman dan pemegang hak cipta karya seni. motif segi empat belah ketupat yang digabung dengan motif aksara lontara, geometris, dan tumbuhan. Motif aksara lontara dan segi empat belah ketupat adalah penerapan unsur budaya lokal pada benda keramik. Aksara lontara sebagai hiasan pada keramik terkadang hanya huruf-huruf tertentu yang digoreskan secara berulang-ulang (redundance) melingkari badan keramik.

Selain itu, ada pula tulisan berupa semboyan atau falsafah hidup. Sedang motif segi empat belah ketupat sepintas merupakan motif geometris, namun sesungguhnya adalah bentuk sulapa eppa yang dalam kebudayaan BugisMakassar mempunyai makna yang sangat dalam. Di samping itu, ditemukan pula motif berupa kaligrafi Arab yang dilukis di atas piring dipadu dengan motif-motif lainnya. Kaligrafi Arab yang diangkat sebagai motif pada keramik hias di Desa Jipang adalah cerminan semangat religius yang kental pada masyarakat suku Bugis-Makassar pada umumnya.

\section{Penutup}

1. Simpulan

Penelitian ini bersifat pengembangan dengan menganalisis desain produk keramik hias di Desa Jipang Kecamatan Bontonompo Kabupaten Gowa. Dari hasil analisis tentang bentuk, motif, dan penerapan unsur budaya lokal pada keramik hias, selanjutnya diajukan beberapa saran demi pengembangan usaha tersebut. Hal itu dimungkinkan karena daerah tersebut kaya dengan bahan baku untuk pembuatan keramik (tanah liat), didukung pula oleh keterampilan pengrajin yang diperoleh secara turun-temurun. Dengan demikian, jika usaha pembuatan keramik tersebut dikelola secara profesional, maka usaha itu akan menjadi sumber penghidupan yang layak bagi masyarakat.

\section{Saran}

Dalam kaitannya dengan upaya pengembangan keramik hias di Desa Jipang, khususnya dalam hal desain produk, dikemukakan beberapa saran atau rekomendasi sebagai berikut.

(1) Para pengrajin disarankan dalam upaya pencarian bentuk dan motif keramik yang lebih kreatif, hendaknya menggali unsur budaya lokal. Penggalian unsur budaya lokal dalam mewujudkan bentuk keramik hias mempunyai keuntungan ganda, yakni selain sebagai upaya pelestarian nilai budaya tradisional, juga akan lebih diminati oleh konsumen karena kekhasannya.

(2) Dalam rangka pengembangan desain produk keramik hias di Desa Jipang perlu perluasan wawasan pengrajin melalui pelatihan atau studi banding ke perusahasaan keramik di daerah lain, misalnya di Pulau Jawa. Sedangkan pelatihan para pengrajin dapat bekerjasama dengan pihak perguruan tinggi dan Departemen Perindustrian.

(3) Dalam kaitan dengan pemasaran produksi pengelola usaha keramik hias di Desa Jipang hendaknya mencari mitra usaha yang menangani masalah pemasaran dan promosi yang dikelola secara profesional. 
